\title{
Economic Cooperation of ASEM Countries and the Trade in Textiles between the European Union and Asian Countries
}

\author{
Agnieszka Drzymała \\ Ph.D., University of Lodz, Faculty of Economics and Sociology \\ Department of World Economy and European Integration, Lodz, Poland \\ e-mail: agnieszka.drzymala@uni.lodz.pl
}

\begin{abstract}
The paper covers the issues of dialogue and cooperation between ASEM countries in the conditions of growing mutual international interdependencies and changing conditions of cooperation at the global level. It presents the ASEM countries which are taking steps aimed at deepening mutual relations. The paper shows one of the many aspects of mutual cooperation. The total trade between the parties is discussed, with a particular focus on the trade in textiles under ASEM. The time range includes the latest available statistics for the period 2013-2016. The data analysis provides the basis for verifying the thesis that the European Union countries import more textiles and clothing than they export to Asian ASEM countries.
\end{abstract}

Keywords: economic cooperation, ASEM, trade, textiles

JEL: F14, F21, F40, F53 


\section{Introduction}

In the present global economy, in which the changes in the structure of economic powers occurred, ever deeper interregional cooperation can be observed. The strategic regions are Europe, headed by the European Union, and Asia, headed by China and Japan. The EU is deepening its relations with Asian countries. This cooperation seems to be beneficial for both parties. However, the EU countries do not necessarily benefit in the area of trade in textiles. The EU countries have been afraid of flooding their markets with cheap products from Asian countries. We should mention the fairly long way to the parties' final agreement on this sensitive issue. Meetings and talks on reducing barriers to trade in textiles were conducted bilaterally as well as in the WTO forum. In 1994, a 10-year program called the Agreement on Textiles and Clothing (ATC) was proposed to gradually reduce restrictions on trade. It was not until January 1, 2005 that full liberalization of the trade in textiles took place. The aim of this paper is to show the total trade between the parties, with a particular focus on the trade in textiles under ASEM (the Asia-Europe Meeting; an intergovernmental process that was started in 1996 to improve relations between Asia and Europe). The thesis states that European Union countries import more textiles and clothing than they export to Asian ASEM countries.

\section{Cooperation between the European Union and Asian countries under ASEM}

As a result of changes taking place in the global economy and the ongoing process of globalization and regional integration, Europe realized the need to establish and strengthen its links with Asian economies. The creation of ASEM was an opportunity to establish special EU relations with East Asian countries, similar to those that the United States maintains with this region thanks to APEC (Gradziuk 2002). Until the mid-1990s, relations between the European Union and Asian countries were based on bilateral agreements with individual Asian countries (Gradziuk 2002). However, it turned out that such a level was not enough to meet the political and economic challenges of the modern world. Both European and Asian parties have come to this conclusion. The willingness to expand economic cooperation was expressed, which allowed for the creation of ASEM.

In November 1994, Singapore and France proposed organizing a European Union - Asia summit. Its objective was to propose the construction of a new partnership between these two regions. The crowning of mutual talks was the start of the functioning of ASEM, the most important forum for EU - East Asian relations. It took place at the first summit in Bangkok ${ }^{\mathbf{1}}$ in March 1996. This event initiated mutual coopera-

1 Meeting of the EU countries and 7 ASEAN countries, Japan, China and South Korea. 
tion (Borkowski 2011). It should be emphasized, however, that ASEM is a specific form of connecting Europe and Asia because it is an informal process of dialogue and cooperation between the countries of both regions in political, economic, cultural and intellectual spheres. The EU also saw the need to complement bilateral relations with individual countries such as Japan and China (Borkowski 2011).

Currently, ASEM comprises 53 members (51 countries and 2 international organizations), including 30 European and 21 Asian countries: all European Union Member States (28); 10 countries of East and Southeast Asia (ASEAN: Philippines, Indonesia, Malaysia, Singapore, Thailand, Brunei Darussalam, Vietnam, Burma, Laos, and Cambodia); since 2008: Japan, China, and the Republic of Korea; since 2010: Mongolia, India, Pakistan, Australia, New Zealand and Russia; since 2012: Bangladesh, Norway and Switzerland; and since 2014 Kazakhstan and Croatia (EU member). ${ }^{2}$ The meetings are also attended by the European Commission and the ASEAN Secretariat.

ASEM is based on three basic pillars $\left.{ }^{3}: 1\right)$ promoting economic cooperation, 2) promoting political dialogue and security, 3) strengthening cultural links between the societies of both continents - Europe and Asia.

The most important economic pillar for the economies is cooperation in eliminating barriers to trade and investment, and in the area of financial and social policy reforms, as well as the fight against crises. ASEM supports previously created and existing contacts. It is not a substitute for other bilateral and multilateral forums of cooperation between the EU and Asian countries. However, it is supposed to help both sides get on and to reconcile their positions through dialogue.

At the global level, ASEM cooperates with other interregional bodies and institutions, including APEC ${ }^{4}$, FEALAC ${ }^{5}$ and the WTO. This cooperation focuses on, i.a., the development of regional trade agreements. Acting in accordance with UN rules, it also implements projects and initiatives promoting ASEM. It plays a significant role today, because it is the second largest assembly in the world, next to the UN.

ASEM is currently a forum for cooperation between European and Asian countries; it is also a symbol of equal and comprehensive partnership. The main and most important form of meeting within ASEM is the summit. ${ }^{6}$ Summits are attended by heads of state and government, and ministers from individual ministries, as well as the current President of the European Commission, also take part. The summits take place every two years (and more recently every year), alternating between a European or Asian country. The summit is also the highest level at which decisions are made. The first summit (ASEM1) took place on 1-2 March, 1996, in Bangkok, Thailand. The last

2 10 $10^{\text {th }}$ ASEM Summit, www.europa.eu (accessed: 7.01.2018).

3 R. Jakimowicz, ASEM - Problemy i wyzwania w pierwszej i drugiej dekadzie XXI w. w kontekście kryzysu Unii Europejskiej, http://ksm.ka.edu.pl/tresc/4-2012-Jakimowicz.pdf (accessed: 27.12.2017).

4 APEC - Asia Pacific Economic Cooperation, www.apec.org (accessed: 20.02.2018).

5 FEALAC - Forum for East Asia -Latin America Cooperation, www.eclac.org (accessed: 7.02.2018).

6 About The Asia-Europe Meeting, www.aseminfoboard.org/about-asem-menu.html (accessed: 7.01.2018). 
one - ASEM 11 - was held in Ulan-Bator, Mongolia, in $2016 .^{7}$ The $12^{\text {th }}$ ASEM Summit (ASEM12) was held on 18-19 October, 2018, in Brussels, Belgium. ${ }^{\mathbf{8}}$

Irrespective of summit meetings, the dialogue between the countries is conducted at ministerial and working level meetings.

ASEM activities are regulated in the AECF document ${ }^{9}$ (Asia Europe Cooperation Framework) adopted at the London Summit in 1998. A new version of the document - AECF 2000 - was adopted during the Seoul Summit in 2000. It contained new commitments and goals corresponding to the beginning of the $21^{\text {st }}$ century.

Along with the development of a common position, it was concluded that ASEM's efforts in the area of economics and finance should be focused on strengthening dialogue and cooperation between the two regions in order to facilitate sustainable economic growth, thus contributing together to global economic dialogue. The talks were also focused on the impact of globalization. In this context, the key priority is to intensify dialogue at the assembly (between senior officials and ministers of economy of the General Assembly for Trade and Investment SOMTI), with particular emphasis on:

- complementing and strengthening actions to deepen the open and multilateral system of trade implemented within the WTO. It was recognized that full participation in the WTO by ASEM partners would strengthen the organization,

- strengthening bilateral trade and investment between Asia and Europe, in particular through the active implementation and further improvement of the Trade Facilitation Action Plan (TFAP) and Investment Promotion Action Plan (IPAP),

- establishing strengthened business for business activities, dialogue and cooperation between the two regions (stressing the key role of AEBF (the Asia-Europe Business Forum ${ }^{\mathbf{1 0}}$ ) and the importance of continuity, facilitating a two-way dialogue between the government and business/private sector, in order to address the specific challenges facing this economic community and paying particular attention to the problems faced by small and medium-sized enterprises,

- strengthening dialogue and cooperation in priority sectors of industry, focusing on the sectors of advanced technology of mutual interest, e.g., agro-technology, food processing, biotechnology, IT and telecommunications (including e-commerce), transport, energy, and environmental engineering.

The most economically involved EU countries (with respect to trade, investments and the transfer of new technologies) in the Asia region are Great Britain, Germany, France and the Netherlands. The most foreign direct investment flow from these countries is recorded as well as an increase in trade. This is of considerable importance for Asian countries because it allows for increased access to the European market. Another important factor is the flow of new technologies (Gradziuk 2002).

$71^{\text {th }}$ ASEM Summit, www.europa.eu (accessed: 7.01.2018).

$812^{\text {th }}$ ASEM Summit (ASEM12), http://www.aseminfoboard.org (accessed: 7.01.2018).

9 Asia Europe Cooperation Framework, www.europa.eu (accessed: 8.01.2018).

10 Asia Europe Business Forum, www.aseminfoboard.org/asia-europe-business-forum (accessed: 9.01.2018). 


\section{The trade in textiles of ASEM countries}

This chapter has been deliberately divided into parts that will be discussed in detail. In this study, the examples of the largest trade flows among ASEM countries were selected. The EU countries will be considered together, most recently as a group of 28 countries, while ASEAN countries, as well as China and Japan, were selected from the group of Asian countries. However, to begin with, the total trade between the EU countries and Asian countries will be presented. The next part will present data on trade in industrial products and textiles between EU and Asian countries. The statistics on total trade, the trade in industrial goods and textiles between the EU countries and ASEAN countries, and between the EU and China and the EU and Japan, will be presented.

\section{The trade in textiles between the EU and Asia}

The next part of the paper is therefore devoted to the trade in textiles between the EU and Asia. The total trade of the European Union with Asian countries in 2013-2016 is shown in Figure 1.

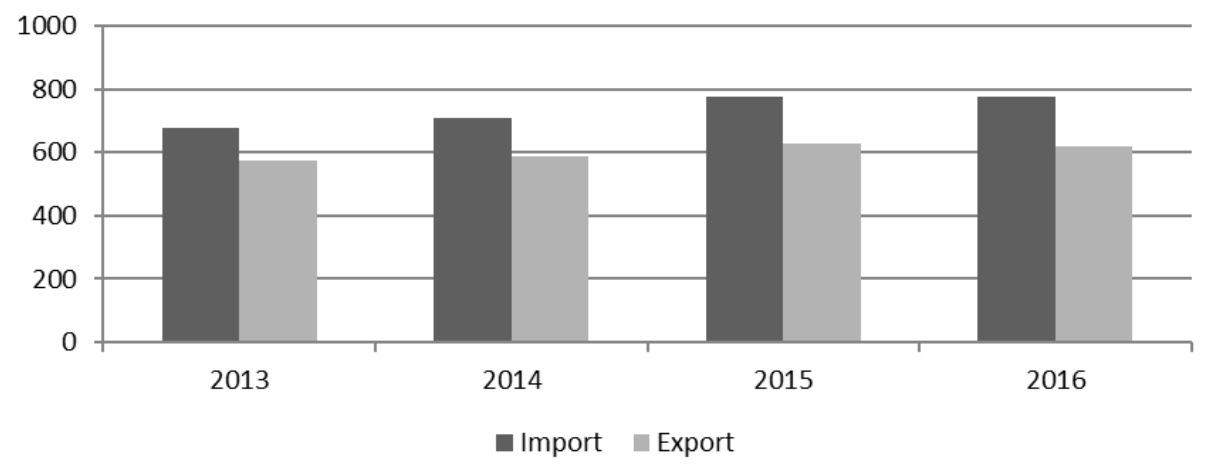

Figure 1. EU imports from Asia and European Union exports to Asia (SITC Rev. 3), 2013-2016, billion EUR

Source: own elaboration based on Eurostat Comext: Trade flows by SITC product grouping 2016, SITC Rev. 3 Product Groups, EU Trade with Asia, http://trade.ec.europa.eu/doclib/docs (accessed: 27.02.2018).

Total EU imports from Asian countries in 2013 amounted to EUR 679.3 billion, while exports were EUR 573.2 billion; in 2014, they were EUR 708.4 billion and EUR 589.6 billion, respectively. In 2015 it totalled EUR 775.6 billion and EUR 629.3 billion, respectively. Total EU imports from Asian countries in 2016 amounted to EUR 774.4 billion while exports were EUR 618.6 billion. Total EU imports from Asian countries in 2016 decreased by $0.2 \%$ in relation to the previous year, and exports in 2016 decreased by $1.7 \%$ compared to 2015 . 


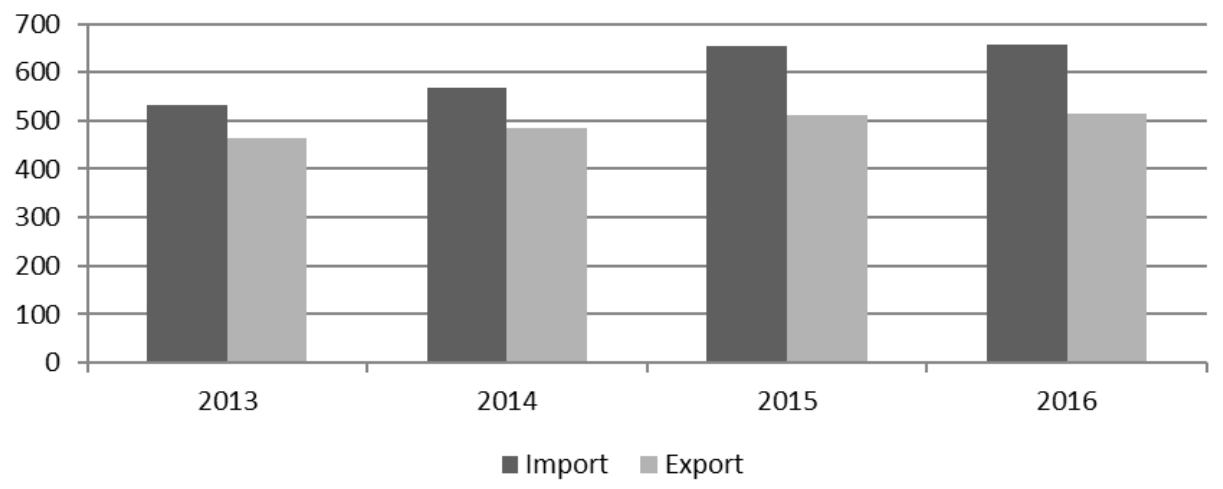

Figure 2. EU trade in manufactures with Asia (SITC Rev. 3), 2013-2016, billion EUR Source: own elaboration based on Eurostat Comext: Trade flows by SITC product grouping 2016, SITC Rev. 3 Product Groups, EU Trade with Asia, http://trade.ec.europa.eu/doclib/docs (accessed: 27.02.2018).

Figure 2 shows the trade in manufactures between the EU and Asia in 2013-2016. Total EU imports of manufactures from Asian countries in 2013 amounted to EUR 533.3 billion while exports were EUR 465.1 billion; in 2014 they were EUR 566.7 billion and EUR 484.2 billion, respectively. In 2015 they were EUR 654.1 billion and EUR 512.6 billion, respectively. EU imports of manufactures from Asia in 2016 amounted to EUR 655.7 billion while exports were EUR 513.7 billion. An increase of $0.2 \%$ was noted both in EU imports of manufactures from Asian countries and in EU exports to Asian countries in 2016 in relation to the previous year.

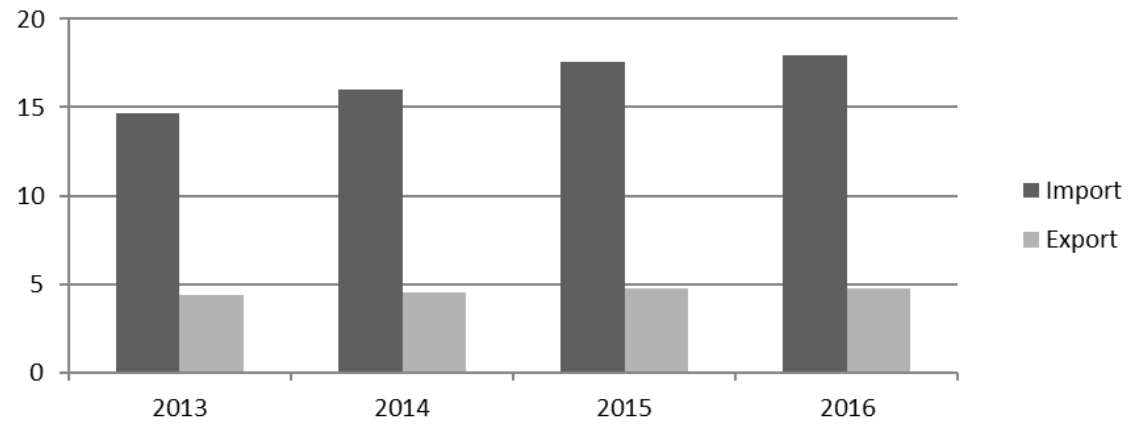

Figure 3. The EU trade in textiles with Asia (SITC Rev. 3), 2013-2016, billion EUR Source: own elaboration based on Eurostat Comext: Trade flows by SITC product grouping 2016, SITC Rev. 3 Product Groups, EU Trade with Asia, http://trade.ec.europa.eu/doclib/docs (accessed: 27.02.2018).

Figure 3 presents the trade in textiles between EU and Asian countries in 20132016. EU imports of textiles from Asia increased over the analyzed years from the level of EUR 14.6 billion in 2013 to EUR 17.9 billion in 2016. Similarly, exports of textiles from the EU to Asia increased from EUR 4.3 billion in 2013 to EUR 4.7 billion 
in 2016. An increase of 2.1\% in EU imports of textiles from Asian countries was recorded in 2016 compared to the previous year. On the other hand, a decrease of $0.4 \%$ in the export of textiles in 2016 in relation to 2015 was noted. There are significant and increasing disproportions in the amounts of imports and exports to the detriment of the EU. The deficit in the trade in textiles was recorded in each of the analyzed years. The EU's negative trade balance with respect to textiles amounted to EUR 10.2 billion in 2013 and EUR 13.2 billion in 2016.

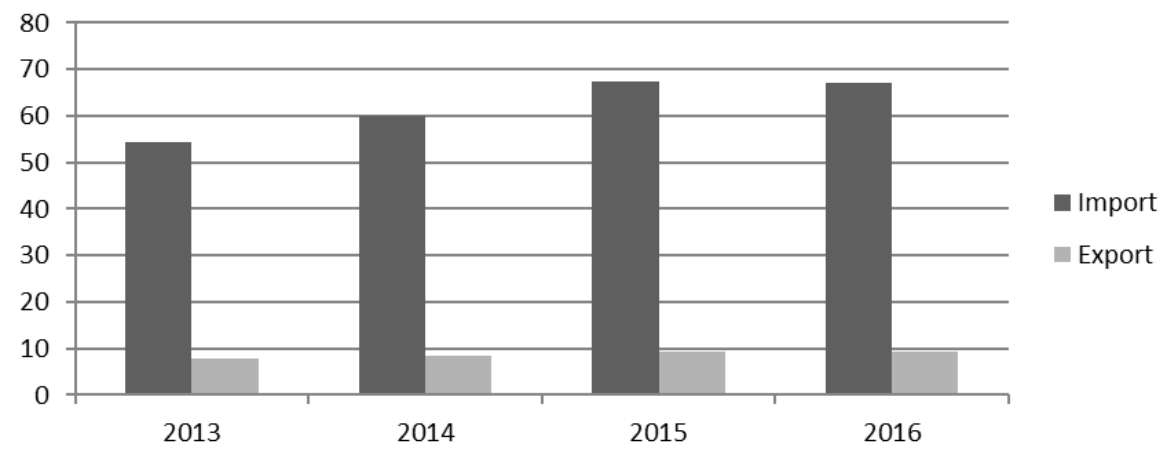

Figure 4. The EU trade in clothing with Asia (SITC Rev. 3), 2013-2016, billion EUR Source: own elaboration based on Eurostat Comext: Trade flows by SITC product grouping 2016, SITC Rev. 3 Product Groups, EU Trade with Asia, http://trade.ec.europa.eu/doclib/docs (accessed: 27.02.2018).

\begin{tabular}{|l|l|}
\hline Import & Export \\
\hline & \\
\hline & \\
\hline
\end{tabular}

Figure 5. The share of trade in manufactures in total EU imports and exports with Asia (SITC Rev. 3), 2016, \%

Source: own elaboration based on Eurostat Comext: Trade flows by SITC product grouping 2016, SITC Rev. 3 Product Groups, EU Trade with Asia, http://trade.ec.europa.eu/doclib/docs (accessed: 27.02.2018).

Figure 4 shows the trade in clothing between the EU and Asian countries in 2013-2016. The import of clothing from Asia increased over the analyzed years from EUR 54.3 billion in 2013 to EUR 67.3 billion in 2015 and EUR 67.1 billion in 2016. Similarly, EU exports of clothing to Asia increased from EUR 7.7 billion in 2013 to EUR 9.4 billion in 2015 and 2016. A decrease of $0.4 \%$ in EU imports of clothing from Asia in 2016 compared to the previous year was noted. There was a decrease of $0.2 \%$ in EU 
exports of clothing to Asian countries in 2016 in relation to 2015. As in the case of textiles, the EU's growing deficit in the trade in clothing with Asian countries in subsequent years is visible. It amounted to EUR 46.6 billion in 2013 and EUR 57.7 billion in 2016.

Figure 5 shows the share of manufactures in total EU imports and exports from and to Asian countries in 2016. EU imports of manufactures from Asia accounted for $84.7 \%$ of the total import. EU exports of manufactures to Asia accounted for $83 \%$ of total exports.

Figure 6 shows the share of textiles and clothing in total imports and exports of EU and Asian countries in 2016. EU imports of textiles from Asia account for $2.3 \%$ of total imports and $2.73 \%$ of exports of manufactures. EU exports of textiles to Asian countries account for $0.8 \%$ of total EU exports and $0.92 \%$ of exports of manufactures.

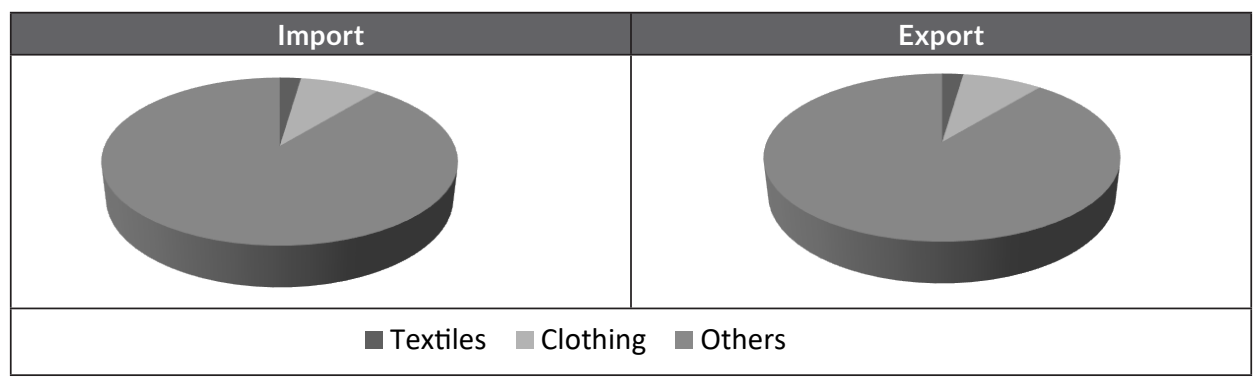

Figure 6. The EU trade in Textiles and Clothing in total imports and exports with Asia (SITC Rev. 3), 2016, \%

Source: own elaboration based on Eurostat Comext: Trade flows by SITC product grouping 2016, SITC Rev. 3 Product Groups, EU Trade with Asia, http://trade.ec.europa.eu/doclib/docs (accessed: 27.02.2018).

Similarly, EU imports of clothing from Asia accounted for $8.7 \%$ of total imports and $10.23 \%$ of the import of manufactures. On the other hand, textiles accounted for $1.5 \%$ of total EU exports to Asia, and $1.82 \%$ of exports of manufactures.

Now, the data on textiles using a different nomenclature of Product HS Section will be compared. As indicated by Eurostat data in the ranking „Total Goods: top product section 2016”, the Section XI “textiles and textile articles” was located in $5^{\text {th }}$ place in terms of the value of EU imports from Asia.

Figure 7 shows the total EU imports and imports of textiles and textile articles (included in Section XI ) from Asian countries in 2013-2016. Total imports increased over the analyzed period from EUR 679.3 billion in 2013 to EUR 774.4 billion in 2016, just like import of textiles and textile articles, which increased from EUR 66.2 billion to EUR 81.7 billion in this period.

Figure 8 shows total EU exports and exports of textiles and textile articles (included in section XI) to Asian countries. Total exports increased over the analyzed period from EUR 573.2 billion in 2013 to EUR 668.6 billion in 2016, just like the import 
of textiles and textile articles, which increased from EUR 12.5 billion to EUR 14.8 billion in this period.

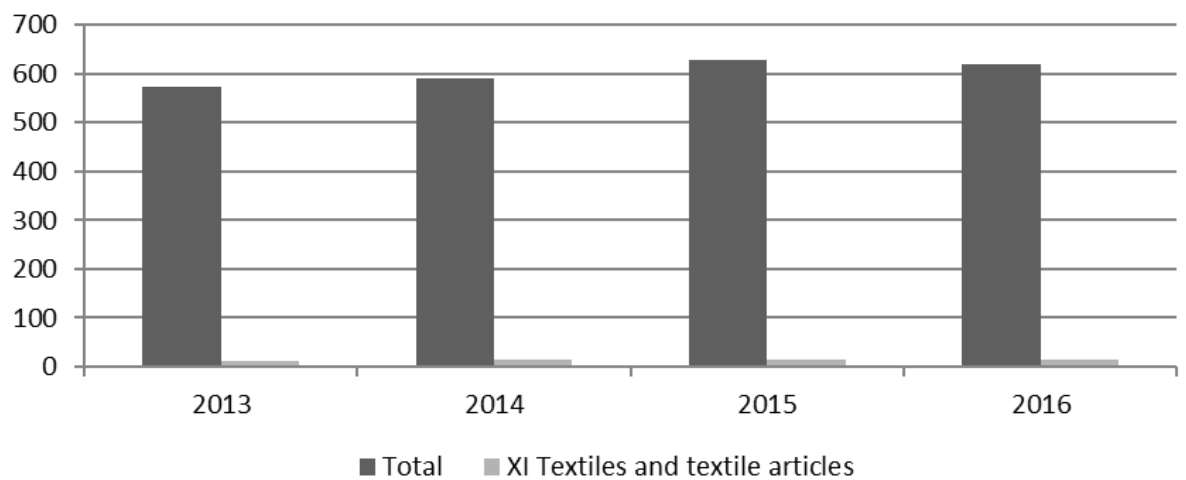

Figure 7. Total EU imports, imports of textiles and textile articles from Asia (HS section), 2013-2016, billion EUR

Source: own elaboration based on Eurostat Comext: EU Trade with Asia (all countries) Trade flows by HS section 2016, http://trade.ec.europa.eu/doclib/docs (accessed: 27.02.2018).

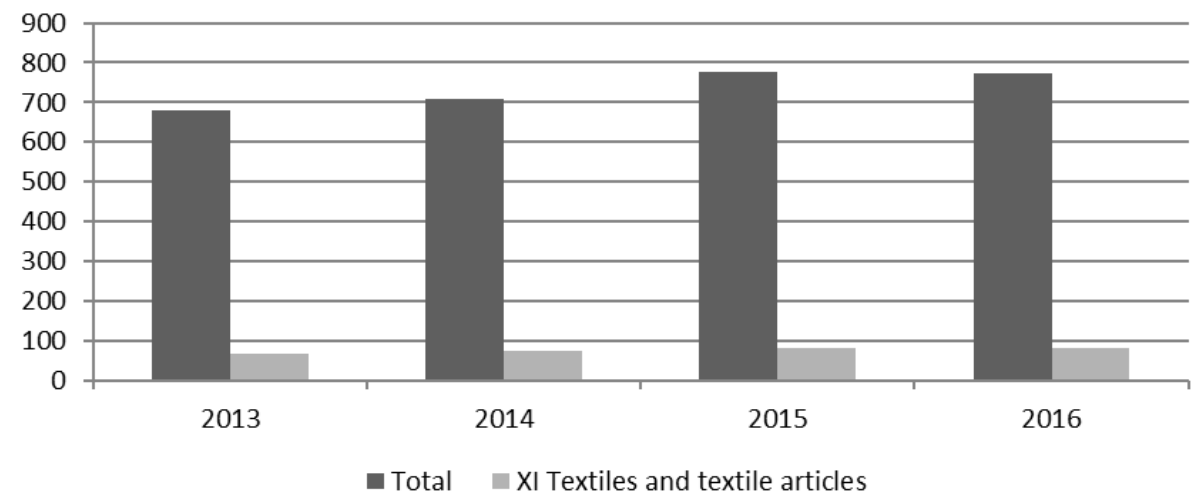

Figure 8. Total EU exports, exports of textiles and textile articles to Asia (HS section), 2013-2016, billion EUR

Source: own elaboration based on Eurostat Comext: EU Trade with Asia (all countries) Trade flows by HS section 2016, http://trade.ec.europa.eu/doclib/docs (accessed: 27.02.2018).

Figure 9 shows EU imports from Asian countries and EU exports to Asian countries of textiles and textile articles (included in Section XI ). In 2016, they constituted 10.6\% of total EU imports from Asian countries and 2.4\% of total EU exports to Asian countries. In 2016, there was an increase in EU imports of textiles and textile articles from Asia by $0.3 \%$ compared to the previous year and an increase in EU exports to Asian countries by $0.6 \%$. In relation to 2015 , significant disproportions in the values of imports and exports in the subsequent analyzed years could be noticed. The EU recorded a trade deficit which amounted to EUR 53.7 billion in 2013 and EUR 66.9 billion in 2016. 


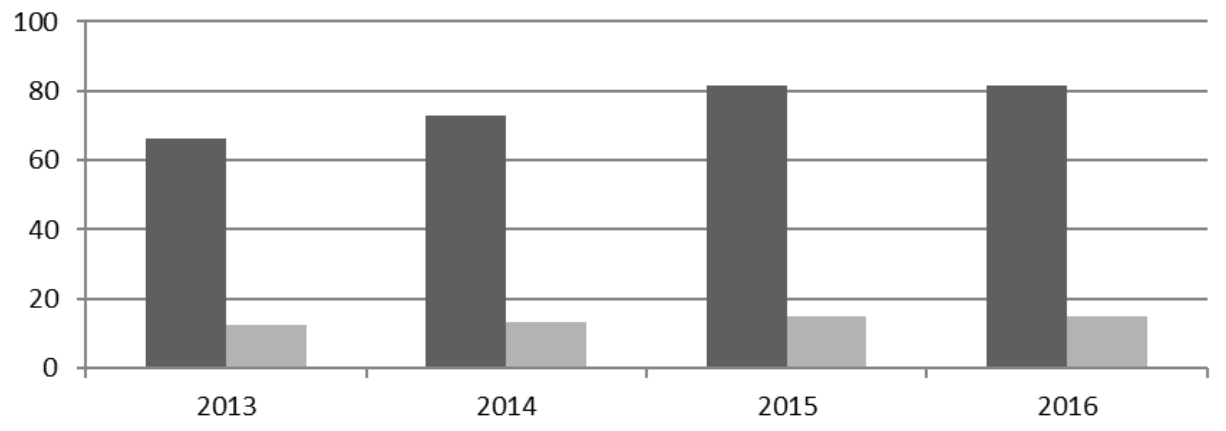

- Import XI Textiles and textile articles Export XI Textiles and textile articles

Figure 9. EU imports from Asia and EU exports to Asia of textiles and textile articles (HS section) 2013-2016, billion EUR

Source: own elaboration based on Eurostat Comext: EU Trade with Asia (all countries) Trade flows by HS section 2016, http://trade.ec.europa.eu/doclib/docs (accessed 27.02.2018).

\section{Trade in textiles between the EU and ASEAN countries}

Some of the ASEM members are ASEAN countries. The next part of the paper is therefore devoted to the total trade and trade in textiles between the EU and the ASEAN countries.

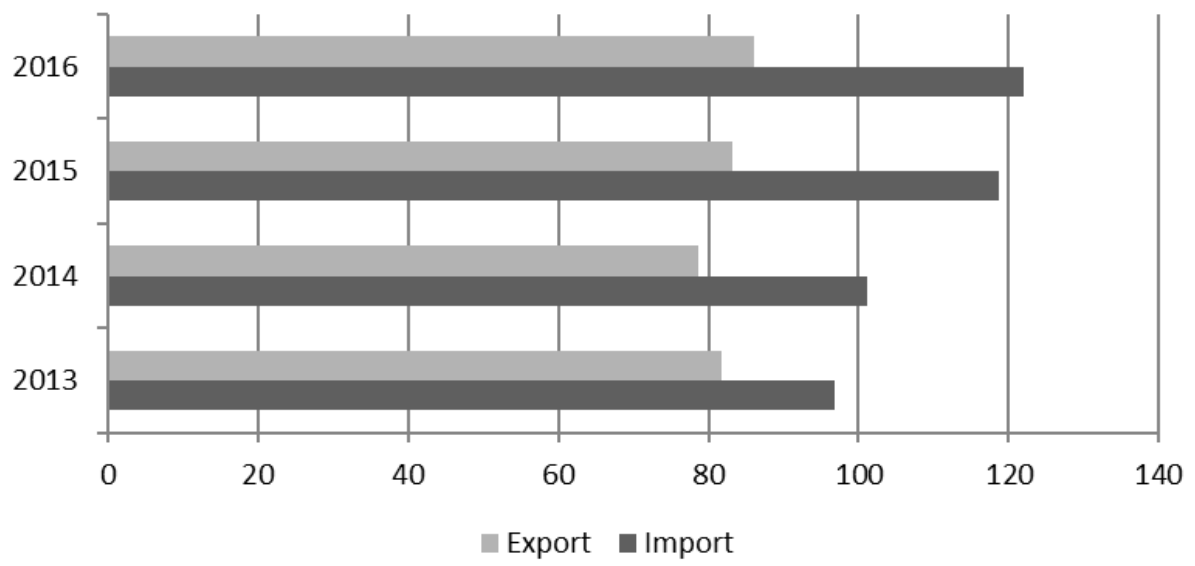

Figure 10. EU trade with ASEAN, 2013-2016 (SITC Rev. 3), billion EUR

Source: own elaboration based on Eurostat Comext: Trade flows by SITC product grouping 2016, SITC Rev. 3 Product Groups, EU Trade with ASEAN, http://trade.ec.europa.eu/doclib/docs (accessed: 27.02.2018).

Figure 10 shows EU trade with ASEAN countries in 2013-2016. EU imports from ASEAN countries over the analyzed period increased from EUR 96.8 billion to EUR 121.9 billion. On the other hand, exports decreased from EUR 81.7 billion in 2013 
to EUR 78.7 billion in 2014 and then increased to EUR 86 billion in 2016. In 2016, EU imports from ASEAN countries increased by $2.7 \%$ compared to the previous year, and EU exports to ASEAN countries increased by 3.4\% compared to 2015.

Figure 11 presents the EU trade in manufactures with ASEAN in 2013-2016. EU imports of manufactures from ASEAN in 2016 accounted for $96.5 \%$ of total EU imports, while EU exports to ASEAN were $83.6 \%$ of total EU exports. EU imports of manufactures from ASEAN increased from EUR 269.8 billion in 2013 to EUR 338.8 billion in 2015 and EUR 332.9 billion in 2016. EU exports of manufactures to ASEAN increased from EUR 125.6 billion to EUR 141.8 billion in 2013-2016. EU imports from ASEAN decreased by $1.7 \%$ in 2016 compared to the previous year, while EU exports to ASEAN increased by $4.1 \%$.

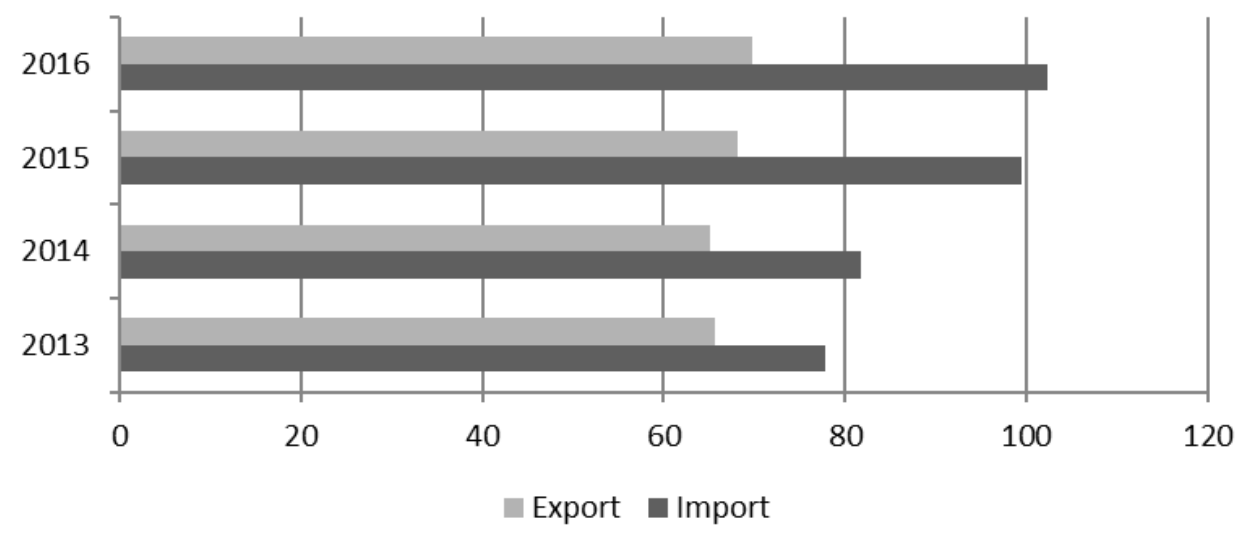

Figure 11. EU trade in manufactures with ASEAN (SITC Rev. 3), 2013-2016, billion EUR Source: own elaboration based on Eurostat Comext: Trade flows by SITC product grouping 2016, SITC Rev. 3 Product Groups, EU Trade with ASEAN, http://trade.ec.europa.eu/doclib/docs (accessed: 27.02.2018).

Figure 12 shows the trade in textiles between the EU and ASEAN in 2013-2016. EU imports of textiles from ASEAN in 2016 accounted for $0.9 \%$ of total EU imports, while EU exports to ASEAN accounted for $0.8 \%$ of total EU exports. EU imports of textiles from ASEAN in the years 2013-2016 increased from EUR 1.04 billion to EUR 1.14 billion. EU exports of textiles to ASEAN in the years 2013-2016 increased from EUR 0.59 billion to EUR 0.7 billion. EU imports of textiles from ASEAN increased in 2016 by $0.6 \%$ compared to the previous year, while EU exports to ASEAN increased by $5.9 \%$.

Figure 13 shows the trade in clothing between the EU and ASEAN in 2013-2016. EU imports of clothing from ASEAN in 2016 accounted for $8.8 \%$ of total EU imports, while EU exports to ASEAN accounted for $0.8 \%$ of total EU exports. EU imports of clothing from ASEAN increased from the level of EUR 7.02 billion in 2013 to EUR 10.8 billion in 2016. EU exports of clothing to ASEAN in the years 2013-2016 increased from EUR 0.48 billion to EUR 0.65 billion. EU imports of clothing from ASEAN in 2016 increased by $8.6 \%$ compared to the previous year and EU exports to ASEAN in 2016 increased by $8.5 \%$ compared to 2015. 


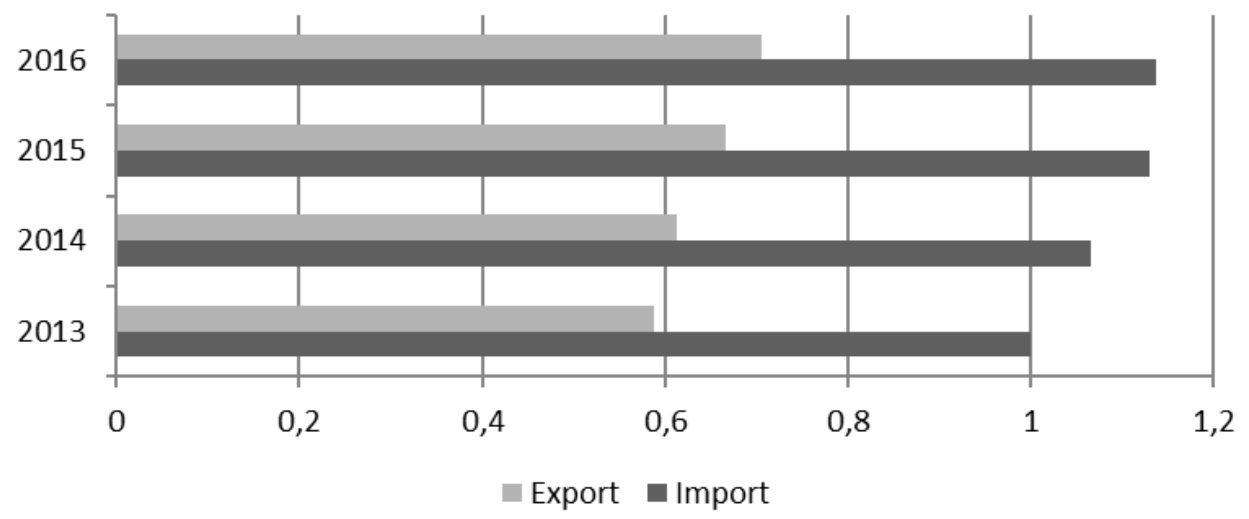

Figure 12. EU trade in textiles with ASEAN (SITC Rev. 3), 2013-2016, billion EUR Source: own elaboration based on Eurostat Comext: Trade flows by SITC product grouping 2016, SITC Rev. 3 Product Groups, EU Trade with ASEAN, http://trade.ec.europa.eu/doclib/docs (accessed: 27.02.2018).

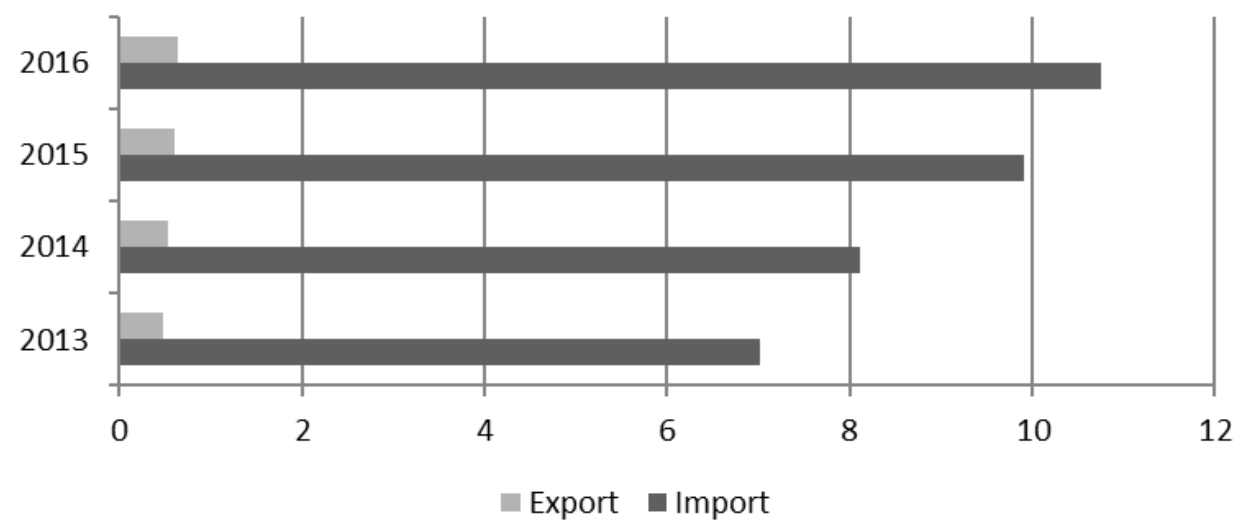

Figure 13. EU trade in clothing with ASEAN (SITC Rev. 3), 2013-2016, billion EUR

Source: own elaboration based on Eurostat Comext: Trade flows by SITC product grouping 2016, SITC Rev. 3 Product Groups, EU Trade with ASEAN, http://trade.ec.europa.eu/doclib/docs (accessed: 27.02.2018).

\section{The trade in textiles between the EU and China}

The next part of the paper relates to the total trade and the trade in textiles between the EU and China.

Figure 14 shows the total EU trade with China in 2013-2016. Total EU imports from China in 2016 decreased by $1.7 \%$ compared to the previous year while EU exports to China decreased by $0.4 \%$. Total EU imports from China increased from EUR 280.2 billion in 2013 to EUR 350.8 billion in 2015 and EUR 344.9 billion in 2016. Total EU exports to China increased from the level of EUR 148.1 billion in 2013 to EUR 170.4 billion in 2015 and EUR 169.7 billion in 2016. 


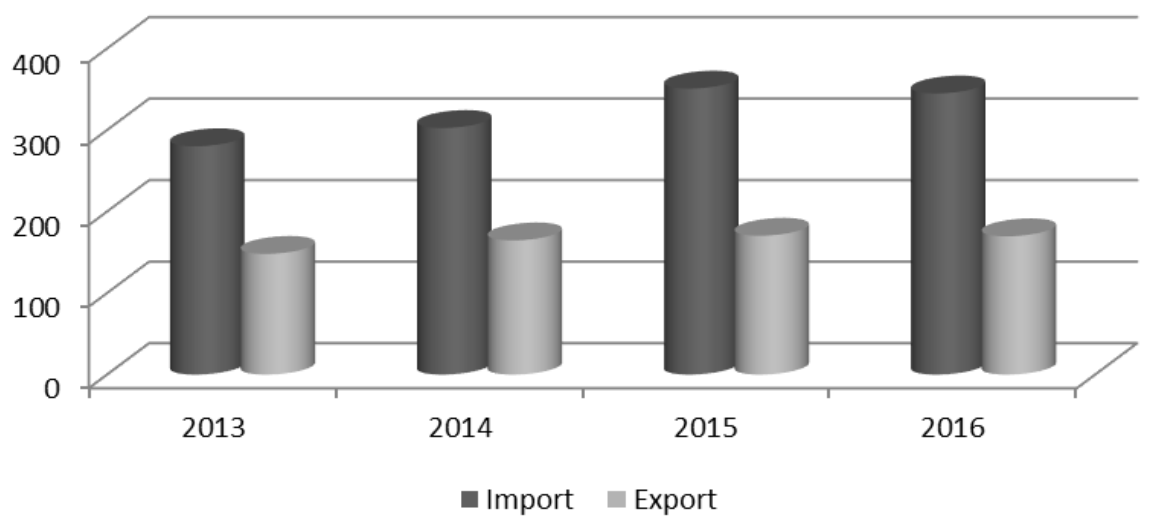

Figure 14. EU trade with China (SITC Rev. 3), 2013-2016, billion EUR

Source: own elaboration based on Eurostat Comext: Trade flows by SITC product grouping 2016, SITC Rev. 3 Product Groups, EU Trade with China, http://trade.ec.europa.eu/doclib/docs (accessed: 27.02.2018).

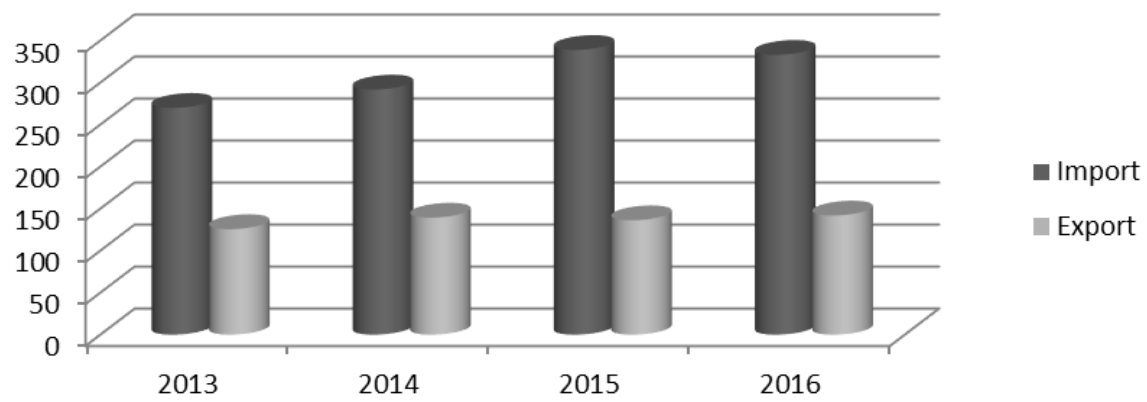

Figure 15. The EU trade in manufactures with China (SITC Rev. 3), 2013-2016, billion EUR Source: own elaboration based on Eurostat Comext: Trade flows by SITC product grouping 2016, SITC Rev. 3 Product Groups, EU Trade with China, http://trade.ec.europa.eu/doclib/docs (accessed 27.02.2018).

Figure 15 shows the trade in manufactures between the EU and China in 2013-2016. EU imports of manufactures from China to the EU in 2016 accounted for $96.5 \%$ of total EU imports while EU exports to China accounted for $83.6 \%$ of total EU exports. EU imports of manufactures from China increased from EUR 269.8 billion in 2013 to EUR 338.8 billion in 2015 and EUR 332.9 billion in 2016. EU exports of manufactures to China increased from EUR 125.6 billion to EUR 141.8 billion in the years 2013 2016. EU imports of manufactures from China decreased by $1.7 \%$ in 2016 compared to the previous year while EU exports to China increased by $4.1 \%$.

Figure 16 shows the trade in textiles between the EU and China in 2013-2016. EU imports of textiles from China in 2016 accounted for $2.7 \%$ of total EU imports while EU exports to China represented $0.7 \%$ of total EU exports. EU imports of textiles from China in the years 2013-2016 increased from EUR 7.3 billion to EUR 9.2 billion. 
EU exports of textiles to China in the years 2013-2016 increased from EUR 1.07 billion to EUR 1.25 billion. EU imports of textiles from China decreased by 7.3\% in 2016 compared to the previous year while EU exports to China increased by $5.5 \%$.

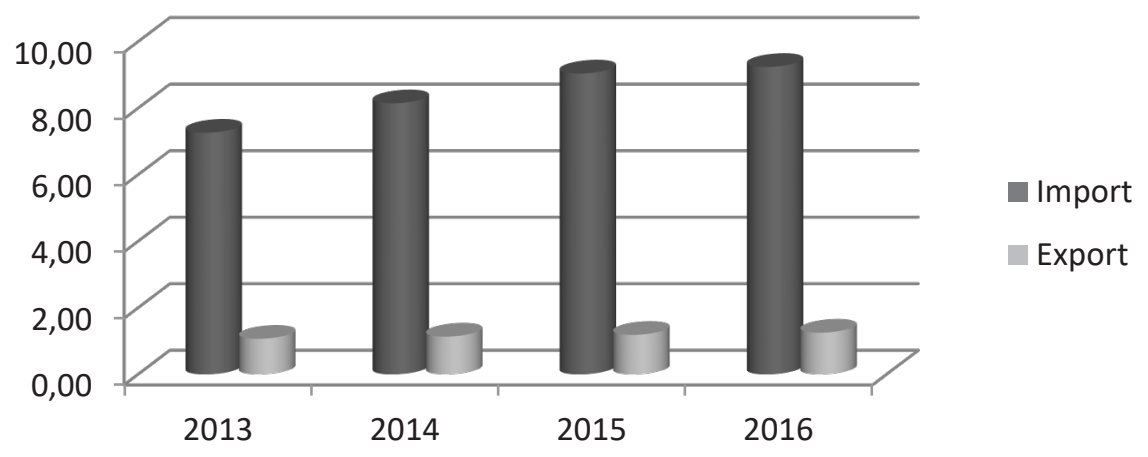

Figure 16. The EU trade in textiles with China (SITC Rev. 3), 2013-2016, billion EUR

Source: own elaboration based on Eurostat Comext: Trade flows by SITC product grouping 2016, SITC Rev. 3 Product Groups, EU Trade with China, http://trade.ec.europa.eu/doclib/docs (accessed: 27.02.2018).

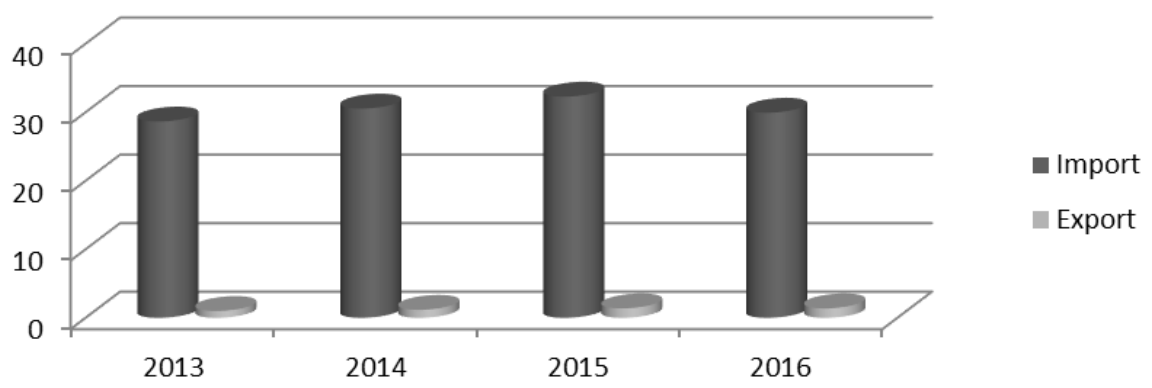

Figure 17. The EU trade in clothing with China (SITC Rev. 3), 2013-2016, billion EUR Source: own elaboration based on Eurostat Comext: Trade flows by SITC product grouping 2016, SITC Rev. 3 Product Groups, EU Trade with China, http://trade.ec.europa.eu/doclib/docs (accessed: 27.02.2018).

Figure 17 shows the trade in clothing between the EU and China in 2013-2016. EU imports of clothing from China accounted for $8.7 \%$ of total EU imports in 2016, while EU exports to China represented $0.8 \%$ of total EU exports. EU imports of clothing from China increased from EUR 28.7 billion in 2013 to EUR 32.3 billion in 2015 and EUR 29.9 billion in 2016. EU exports of clothing to China in the years 20132016 increased from EUR 1.429 billion to EUR 1.49 billion. EU imports of clothing from China and EU exports to China in 2016 fell by $0.3 \%$ compared to the previous year. 


\section{The trade in textiles between the EU and Japan}

The next stage of the study concerns the total trade and the trade in textiles between the EU and Japan.

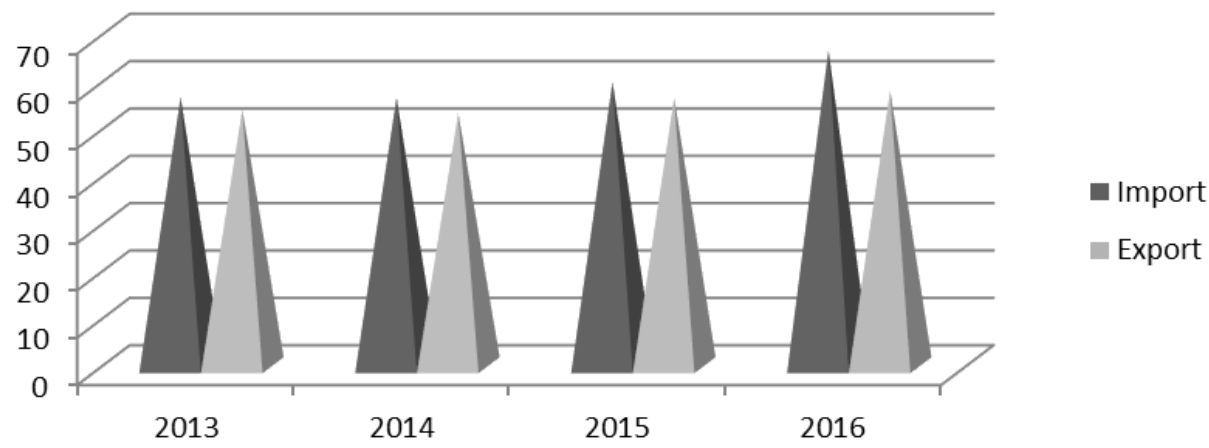

Figure 18. The EU trade with Japan (SITC Rev. 3), 2013-2016, billion EUR

Source: own elaboration based on Eurostat Comext: Trade flows by SITC product grouping 2016, SITC Rev. 3 Product Groups, EU Trade with Japan, http://trade.ec.europa.eu/doclib/docs (accessed: 27.02.2018).

Figure 18 shows the total EU trade with Japan in 2013-2016. Total EU imports from Japan in 2016 increased by $11.3 \%$ compared to the previous year, while EU exports to Japan increased by $2.6 \%$ compared to 2015 . Total EU imports from Japan in 20132016 increased from EUR 56.6 billion to EUR 66.6 billion. Total EU exports to Japan increased from EUR 54 billion to EUR 58 billion in this period.

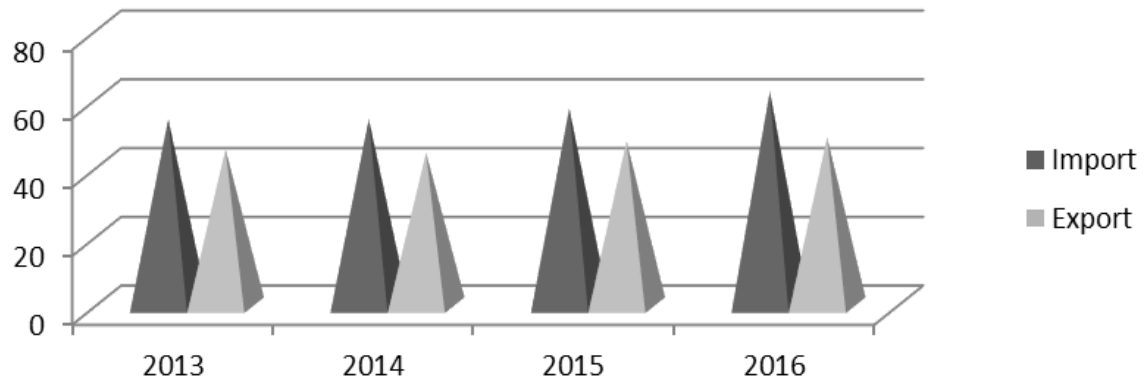

Figure 19. The EU trade in manufactures with Japan (SITC Rev. 3), 2013-2016, billion EUR Source: own elaboration based on Eurostat Comext: Trade flows by SITC product grouping 2016, SITC Rev. 3 Product Groups, EU Trade with Japan, http://trade.ec.europa.eu/doclib/docs (accessed: 27.02.2018).

Figure 19 shows the trade in manufactures between the EU and Japan in 2013-2016. EU imports of manufactures from Japan accounted for $93.5 \%$ of total EU imports in 2016, while EU exports to Japan accounted for $84.2 \%$ of total EU exports. EU imports of manufactures from Japan in the years 2013-2016 increased from EUR 54.2 
billion to EUR 62.3 billion. EU exports of to Japan in the years 2013-2016 increased from EUR 54.2 billion to EUR 62.3 billion. EU imports of manufactures from Japan increased in 2016 by $8.6 \%$ compared to the previous year, while EU exports to Japan increased by $2.4 \%$.

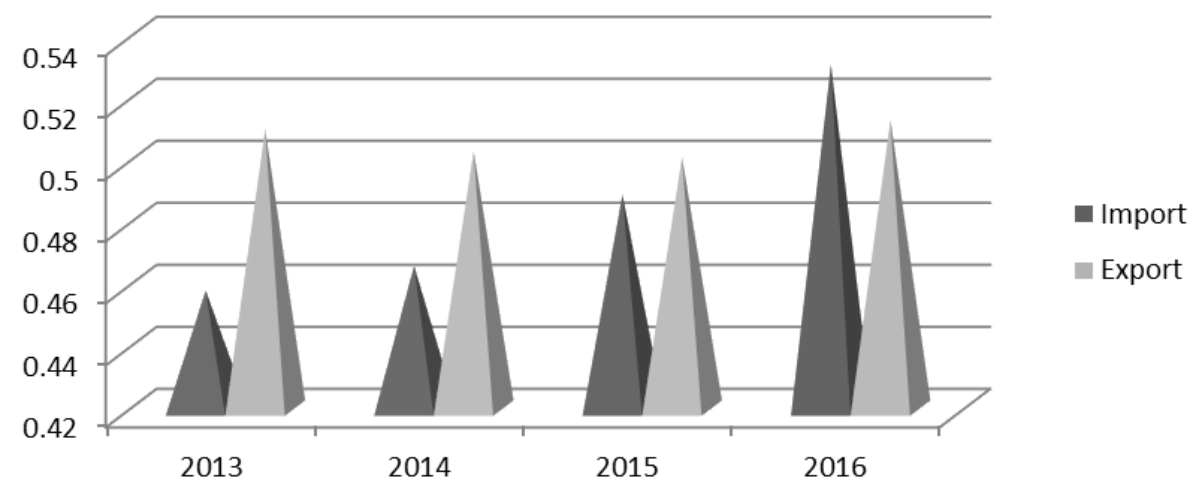

Figure 20. The EU trade in textiles with Japan (SITC Rev. 3), 2013-2016, billion EUR

Source: own elaboration based on Eurostat Comext: Trade flows by SITC product grouping 2016, SITC Rev. 3 Product Groups, EU Trade with Japan, http://trade.ec.europa.eu/doclib/docs (accessed: 27.02.2018).

Figure 20 shows the trade in textiles between the EU and Japan in 2013-2016. EU imports of textiles from Japan accounted for $93.5 \%$ of total EU imports, while EU exports to Japan accounted for $84.2 \%$ of total EU exports. EU imports of textiles from Japan in the years 2013-2016 increased from EUR 54.2 billion to EUR 62.3 billion. EU exports of textiles to Japan in the years 2013-2016 increased from EUR 54.2 billion to EUR 62.3 billion. EU imports of textiles from Japan in 2016 increased by $8.6 \%$ compared to the previous year, while EU exports to Japan increased by $2.5 \%$.

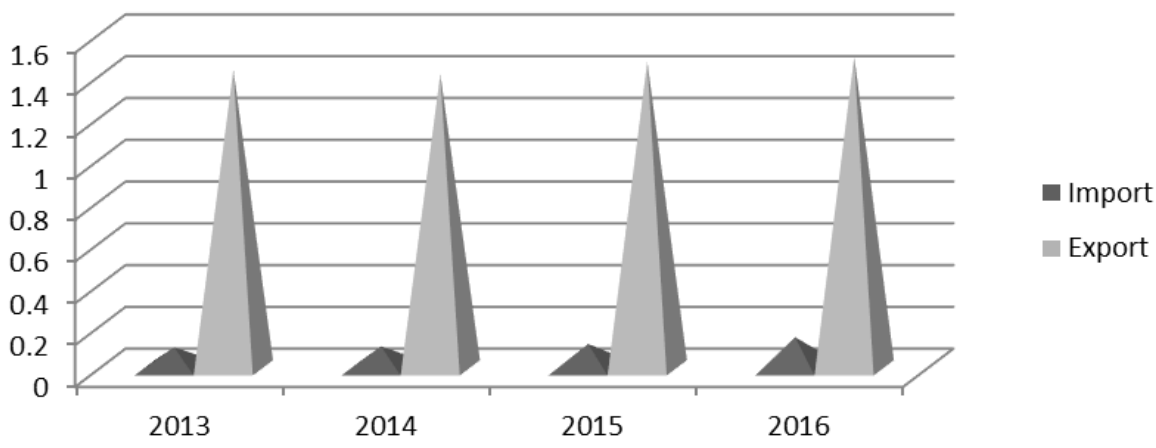

Figure 21. The EU trade in clothing with Japan (SITC Rev. 3), 2013-2016, billion EUR Source: own elaboration based on Eurostat Comext: Trade flows by SITC product grouping 2016, SITC Rev. 3 Product Groups, EU Trade with Japan, http://trade.ec.europa.eu/doclib/docs (accessed: 27.02.2018). 
Figure 21 shows the trade in clothing between the EU and Japan in 2013-2016. EU imports of clothing from Japan in 2016 accounted for $0.2 \%$ of total EU imports, while EU exports to Japan accounted for $2.6 \%$ of total EU exports. EU imports of clothing from Japan in the years 2013-2016 increased from EUR 0.098 billion to EUR 0.147 billion. EU exports of clothing to Japan in the years 2013-2016 increased from EUR 1.429 billion to EUR 1.49 billion. EU imports of clothing from Japan increased in 2016 by $27.7 \%$ compared to the previous year, while EU exports to Japan increased by $1.6 \%$. The reason for this situation may be the desire to follow fashion, and thus imports of the latest collections of clothes to Japan from the EU countries.

\section{Conclusion}

It can be confirmed that currently, ASEM is an extremely important micro- and macroeconomic forum for direct dialogue between the European Union and its Asian partners. It is an important instrument of cooperation for both regions, and at the same time, an instrument of bilateral and global-scale cooperation. ASEM meetings have gained importance in the time of the global economy and the serious challenges which are not only associated with the crises. These meetings became necessary. It should be noted that it is thanks to this initiative that the European Union has implemented its plans to influence global politics through a proper and systematically introduced interregional policy.

The benefits of cooperation within ASEM are also visible in Asian countries. Firstly, it improves their image in the world. Secondly, thanks to the cooperation, they become "closer" to the partners. In addition, all Asian countries, although they do not form a homogeneous group, define their economies as pro-export. Most of these countries have undertaken internal development reforms, and others have started export expansion hoping to increase their access to the European market. They expect that increased trade will lead to the growth of their economies and to economic development. Economic cooperation and trade within ASEM are, therefore, systematically developing.

The cooperation within the ASEM group seems to be beneficial for both the European Union and the Asian countries. Economic links, including trade, imply further cooperation. However, in the area of textiles, the European Union has been recording a trade deficit for years. Research shows that ASEAN countries, as well as China and Japan, are important and the largest partners for the EU. The presented data point to the growing imports of textiles from these countries to the EU in the analyzed years 2013-2016. The detailed data for 2016 shows the situation in the market.

In 2016, the EU imported goods worth EUR 121.9 billion from ASEAN countries and exported goods worth EUR 86 billion. The deficit amounted to EUR 35.9 billion. Imports of textiles to the EU from ASEAN amounted to EUR 1.137 billion and exports to EUR 0.706 billion. Imports of clothing to the EU from these countries amounted to EUR 10.75 billion and exports to EUR 0.65 billion. The deficit amounted to EUR 10.1 billion. 
The total import of goods to the EU from China in 2016 amounted to EUR 344.9 billion and the EU exported to China goods worth EUR 169.7 billion. The deficit amounted to EUR 175.2 billion. Imports of textiles to the EU from China amounted to EUR 9.24 billion while EU exports to China were EUR 1.25 billion. The deficit amounted to EUR 7.99 billion. The EU imported clothing worth EUR 29.9 billion from China and exported clothing worth EUR 1.38 billion. The deficit amounted to EUR 28.52 billion.

The EU imported goods worth EUR 66.6 billion from Japan in 2016 while the EU exported goods to Japan worth EUR 58 billion. Thus, the deficit was EUR 8.6 billion. Imports of textiles to the EU from Japan amounted to EUR 0.531 billion and exports to EUR 0.513 billion. A deficit of EUR 0.018 billion was recorded. It is worth mentioning that imports of clothing to the EU from Japan in 2016 amounted to EUR 0.147 billion and exports to EUR 1.49 billion. Thus, the EU recorded a surplus, i.e., a positive balance of EUR 1.343 billion.

Considering the above, it can be confirmed that EU countries import more textiles and clothing than they export to Asian ASEM countries. However, it should be emphasized that EU countries export more clothing to Japan than they import.

\section{References}

$10^{\text {th }}$ ASEM Summit, www.europa.eu (accessed: 7.01.2018).

$12^{\text {th }}$ ASEM Summit (ASEM12), http://www.aseminfoboard.org (accessed: 7.01.2018).

About The Asia-Europe Meeting, www.aseminfoboard.org/about-asem-menu.html (accessed: 7.01.2018).

APEC - Asia Pacific Economic Cooperation, www.apec.org (accessed: 20.02.2018).

ASEM Summit (Asia - Europe Meeting) in Brussels, www.eurofundsNEWS.pl (accessed: 7.01.2018).

ASEM, www.european-council.europa.eu (accessed: 7.01.2018).

Asia Europe Business Forum, www.aseminfoboard.org/asia-europe-business-forum (accessed: 9.01.2018).

Asia Europe Cooperation Framework, www.europa.eu (accessed: 8.01.2018).

Asia - Europe Meeting, www.asem.org (accessed: 7.01.2018).

Borkowski, P.J. (2011), ASEM jako przejaw globalizacji, [in:] J. Nakonieczna, Zajączkowski, J. (ed.) Azja Wschodnia i Azja Południowa w stosunkach międzynarodowych, Wydawnictwo Uniwersytetu Warszawskiego, Warszawa 2011.

Eurostat Comext: Trade flows by SITC product grouping 2016, SITC Rev.3 Product Groups, UE Trade with Asia, http://trade.ec.europa.eu/doclib/docs (accessed: 27.02.2018).

Eurostat Comext: Trade flows by SITC product grouping 2016, SITC Rev.3 Product Groups, UE Trade with ASEAN, http://trade.ec.europa.eu/doclib/docs (accessed: 27.02.2018). 
Eurostat Comext: Trade flows by SITC product grouping 2016, SITC Rev.3 Product Groups, UE Trade with China, http://trade.ec.europa.eu/doclib/docs (accessed: 27.02.2018).

Eurostat Comext: Trade flows by SITC product grouping 2016, SITC Rev.3 Product Groups, UE Trade with Japan, http://trade.ec.europa.eu/doclib/docs (accessed: 27.02.2018).

Eurostat Comext: UE Trade with Asia (all countries) Trade flows by HS section 2016, http://trade.ec.europa.eu/doclib/docs (accessed: 27.02.2018).

FEALAC - Forum for East Asia -Latin America Cooperation, www.eclac.org (accessed: 7.02.2018).

Gradziuk, A. (2002), Stosunki Unii Europejskiej z Azja Wschodnia i konsekwencje dla Polski, "Biuletyn Polskiego Instytutu Spraw Międzynarodowych”, No. 85.

Jakimowicz R., ASEM - Problemy $i$ wyzwania w pierwszej i drugiej dekadzie XXI w. w kontekście kryzysu Unii Europejskiej, http://ksm.ka.edu.pl/tresc/4-2012-Jakimowicz.pdf (accessed: 27.12.2017).

Ministerial Meetings, www.eeas.europa.eu (accessed: 7.01.2018).

Oziewicz, E. (2007), Dylematy rozwoju gospodarczego krajów Azji Południowo-Wschodniej na tle procesów globalizacyjnych, Wydawnictwo Uniwersytetu Gdańskiego, Gdańsk 2007.

SOM - Senior Officials Meeting, www.aseminfoboard.org (accessed: 9.01.2018).

The Asia-Europe Cooperation Framework, www.eeas.europa.eu/asem/docs/ aecf_2000_en.pdf (accessed: 7.01.2018).

The Asia - Europe Meeting (ASEM), www.aseminfoboard.org (accessed: 7.01.2018).

Wysokińska, Z., Witkowska, J. (2016), Zrównoważony rozwój. Wybrane aspekty makroi mikroekonomiczne, Wydawnictwo Uniwersytetu Łódzkiego, Łódź 2016.

\section{Streszczenie}

\section{Współpraca krajów ASEM a handel tekstyliami między UE i wybranymi krajami azjatyckimi}

Artykuł obejmuje problematykę dialogu i współpracy krajów ASEM powstałych w warunkach narastania wzajemnych współzależności międzynarodowych i zmieniających się warunków współpracy na poziomie globalnym. Pokazuje państwa ASEM, które podejmują działania na rzecz pogłębienia wzajemnych relacji. Artykuł pokazuje jeden z wielu aspektów wzajemnej współpracy. Autorka poddaje analizie handel ogółem, a w szczególności handel tekstyliami w ramach ASEM. Zakres czasowy obejmuje ostatnie dostępne statystyki dotyczące lat 2013-2016. Ich analiza dała podstawę do zweryfikowania tezy, iż kraje Unii Europejskiej importują więcej tekstyliów i odzieży niż wynosi ich eksport do krajów Azjatyckich ASEM.

Słowa kluczowe: współpraca gospodarcza, ASEM, handel, tekstylia 